\title{
PHYSIOLOGICAL RESPONSES OF BROILER CHICKENS AS INFLUENCED BY EARLY AGE HEAT CONDITIONING AND DIETARY ANTIOXIDANT SUPPLEMENTATION
}

\author{
A. Gouda ${ }^{1}$; M.M.A. El-Moniary ${ }^{1}$; E.F. Eldaly ${ }^{1}$; I. El-Wardany ${ }^{2}$ and A.A. Hemid $^{2}$ \\ ${ }^{1}$ Animal production Dept., Agric. \& Biologic. Research Division, National Research Center, Dokki, \\ Cairo, Egypt. \\ ${ }^{2}$ Poultry. Production Dept., Fac. of Agric. Ain Shams Univ., Shoubra El- Kheima, Cairo, Egypt.
}

\section{SUMMARY}

$\mathrm{T}$

wo hundred and forty 1-d old commercial broiler chicks (Cobb) were allotted to two groups of 120 chicks. The first group was the control (Non heat conditioning). The second one was exposed to $40 \pm 1^{\circ} \mathrm{C}$ for $24 \mathrm{~h}$ at $5 \mathrm{DOA}$, (early age heat conditioning). Each group was further subdivided into 4 sub-groups of 30 birds each, the first sub-group was control group, the second was fed basal diet supplemented with $200 \mathrm{IU} / \mathrm{kg}$ diet vitamin $\mathrm{E}$ and $0.8 \mathrm{mg} / \mathrm{kg}$ diet chromium methionine, the third was fed basal diet supplemented with $200 \mathrm{IU} / \mathrm{kg}$ diet vitamin $\mathrm{E}$ and $0.3 \mathrm{mg} / \mathrm{kg}$ diet selenium methionine and the fourth was fed basal diet supplemented with $200 \mathrm{IU} / \mathrm{kg}$ diet vitamin $\mathrm{E}, 0.8 \mathrm{mg} / \mathrm{kg}$ diet chromium methionine and $0.3 \mathrm{mg} / \mathrm{kg}$ diet selenium methionine, to investigate the effects of early age of heat conditioning and some antioxidants supplementation on some physiological changes. Results showed that Chicks exposed to early age heat conditioning recorded significantly higher $(\mathrm{P}<0.05) \mathrm{BW}$, BWG, FI and FCR compared with non heat conditioning chicks at 21 and 42 DOA. There were significant $(\mathrm{P}<0.05)$ effects of dietary supplements on BW, BWG, FI and FCR at 21 and 42 DOA, and also by the interaction between early age heat conditioning and dietary supplements. Early age heat conditioning had significant $(\mathrm{P}<0.05)$ effect on $\mathrm{Hb}, \mathrm{HT}, \mathrm{RBC}$ 'S, MCHC and MCV levels at $21 \mathrm{DOA}$, but MCH values was insignificantly influenced. Significant $(\mathrm{P}<0.05)$ effects of early age heat conditioning significant $(\mathrm{P}<0.05)$ effects on Hb, HT, and RBC'S levels of broiler chicks at 42 DOA, however, MCH, MCHC and MCV levels were not affected. Dietary supplements (regardless early age heat conditioning) significantly increased $\mathrm{Hb}$, HT, RBC'S, MCH, MCHC and MCV levels at 21 DOA and at 42 DOA except MCH, MCHC and MCV which were not significant. The interaction between early age heat conditioning and dietary supplements was significant for most of the hematological parameters studied either at 21 or 42 DOA. Early age heat conditioning had a significant $(\mathrm{P}<0.05)$ effect on $\mathrm{H} / \mathrm{L}$ ratio, but the effect of dietary supplements alone was not significant at 21 and 42 DOA. Based on the results of the present study it is concluded that early age heat conditioning of broiler chicks and dietary supplements by Vit.E; organic chromium or organic selenium in combination could be recommended for alleviating the negative effects of heat stress during the summer season, on broiler chicks performance.

Keywords: Broiler, performance, Blood, early age heat conditioning, Vitamin E, selenium, Chromium.

\section{INTRODUCTION}

Poultry production in tropical countries is affected by many challenges especially during the hot humid summer season. High ambient temperature as encountered in Egypt and many other countries during the summer season can generate a state of stress and evokes a combination of behavioral, biochemical and physiological changes. This generally resulted in economic losses by reduction in broiler performance and increased mortality due to acute heat stress. Homeostasis is constantly challenged by intrinsic and extrinsic stressors (Lin et al., 2006). Heat stress is of major concern for poultry industry, especially in the hot regions. The important traits governing productivity (growth performance, immune suppression and high mortality rate ..... etc) are adversely affected by heat stress (Mujahid et al., 2006, 2008 and Niu et al., 2009). Physiological events associated with hyperthermia can potentially promote reactive oxygen species formation which results in the disturbance of balance between the oxidation and antioxidants defense systems, causing lipid peroxidation (LPO), in cell membranes, free radical peroxidation and oxidative injury in biological molecules, DNA and proteins (Lin et al., 2006; Mujahid et al., 2006 and 2007 and Aslam et al., 2010), Further more, heat stress increases mineral and vitamin mobilization from tissues and their excretion, thus may exacerbate a marginal vitamin and mineral deficiency or an increased mineral and vitamin requirement, several methods are available to alleviate the negative effects of heat stress, mostly focused on dietary manipulation.

Presently a number of programmers have been used to introduce simplified and practical techniques to alleviate the adverse effects of heat stress in broiler chickens. One of the practical approaches that have yielded promising results is altering birds' abilities to cope with high ambient temperatures by early-age heat conditioning; converging evidence suggests that stressful experiences during the neonatal stage can 


\section{Gouda et al.}

have considerable impact on various facets of an animal's physiology and behavior. Exposure of 5-d-old broiler chicks to elevated temperature improved their survivability at 42 DOA after environmental exposure (El-Moniary et al., 2010; El-Wardany et al., 2012 and Hemid et al., 2013).

Dietary chromium supplementation has been reported to have a positive effect on growth rate and feed efficiency of growing poultry under stress conditions (Sahin et al. 2001 and Lien et al. 1999). Stress thus may exacerbate a marginal chromium $(\mathrm{Cr})$ deficiency or an increased $\mathrm{Cr}$ requirement, $\mathrm{Cr}$ is used in the poultry diet because of the reported benefits of $\mathrm{Cr}$ supplementation in broiler under heat stress because of the fact that stress condition increase chromium mobilization from the tissues that is irreversibly excreted (Sahin et al., 2002 and 2003). Cr plays a regulatory role in insulin action and consequently, in nutrient metabolism (Sands and Smith, 2002). It is also an integral part of bimolecular such as glucose tolerance factor and chromodulin, a cofactor of certain enzymes and necessary for stabilization of proteins and nucleic acids. Ghazi et al., (2012) studied the effect of different concentrations of organic and inorganic chromium on broilers they found the dietary supplementation of both organic and inorganic chromium significantly improved $\mathrm{H} / \mathrm{L}$ ratio.

Selenium supplementation especially at 0.2 and $0.3 \mathrm{mg} / \mathrm{kg}$ diet significantly $(\mathrm{P} \leq 0.05)$ increased live body weight of chicks (El-Sheikh et al. 2010 and Zhou and Wang 2011). In contrast, Patton et al. (2002) suggested that adding selenium yeast at $0.1,0.2$ or $0.3 \mathrm{ppm}$, was not significantly $(P<0.05)$ affected feed intake. Similar results were observed by (Spears et al., 2003; Jiakui and Xiaolong 2004; Utterback et al 2005 and Ševčíková et al., 2006). El-Sheikh et al. (2010) stated that, selenium supplementation especially at 0.2 and $0.3 \mathrm{mg} / \mathrm{kg}$ diet significantly $(\mathrm{P} \leq 0.05)$ increased blood hemoglobin $(\mathrm{Hb})$ and red blood cells ( $\mathrm{RBC}$ `s) for groups fed 0.2 and 0.3 selenium compared with the control group.

Vitamin E (Vit.E) were discovered and its role as an antioxidants was further characterized (Wolf, 2005). The Vit.E that is integrated into cellular membranes exerts its antioxidant effects by intercepting peroxyl radicals more rapidly than can polyunsaturated fatty acids (Burton and Traber, 1990). Abdukalykova and Ruiz-Feria (2006) found that body weight was higher when broilers fed on feed supplemented with vitamin. Elaroussi et al. (2007) reported that quail chicks fed on diets containing 0,1 , 5 or 10 times the NRC 12 and $25 \mathrm{mg} / \mathrm{kg}$ diet recommended supplements of vitamin E, Significant differences between the 4 dietary treatments indicated that as the levels of vitamin $\mathrm{E}$ increased, the percentage of erythrocytes haemolysed activity decreased, whereas $\mathrm{Hb}$ concentration increased, they concluded that diet contains in quail chicks 5 times the recommended NRC for vitamin $\mathrm{E}$ was adequate to increase $\mathrm{Hb}$ concentration.

Therefore, the objective of the present study were to evaluate the effect of different approaches (early age heat conditioning; increasing dietary levels of organic chromium, organic selenium and Vitamin E) on productive performance and some hematological_parameters of broiler chicks reared under summer stress conditions. Finally, results from this study could provide a fundamental knowledge for using early age heat conditioning and dietary supplements by Vit.E; organic chromium or organic selenium in combination to reduce improve productive performance and some hematological parameters of broiler chicks under hot climates of summer season in Egypt.

\section{MATERIALS AND METHODS}

\section{Experimental procedures}

A total of 240 one day old commercial broiler chicks (Cobb) were obtained also from the previous hatchary. They were divided into two groups of 120 chicks. Each group was subdivided into 4 sub-groups of 30 chicks, the first sub-group was the control group, the second was fed basal diet supplemented with $200 \mathrm{IU} / \mathrm{kg}$ diet vitamin $\mathrm{E}$ and $0.8 \mathrm{mg} / \mathrm{kg}$ diet chromium methionine, the third was fed basal diet supplemented with $200 \mathrm{IU} / \mathrm{kg}$ diet vitamin $\mathrm{E}$ and $0.3 \mathrm{mg} / \mathrm{kg}$ diet selenium methionine and the fourth was fed basal diet supplemented with $200 \mathrm{IU} / \mathrm{kg}$ diet vitamin E, $0.8 \mathrm{mg} / \mathrm{kg}$ diet chromium methionine and 0.3 $\mathrm{mg} / \mathrm{kg}$ diet selenium methionine. At 5 day of age the first group was exposed to $40 \pm 1^{\circ} \mathrm{C}$ for $24 \mathrm{~h}$ (Heat conditioning, $\mathrm{HC}$ ), while the second one was kept at the normal brooding $\left(32 \pm 1^{\circ} \mathrm{C}\right)$ temperature (Non heat conditioning, N.H.C). At 42 DOA all groups were exposed to $41 \pm 1^{\circ} \mathrm{C}$ for $1 \mathrm{~h}$. Feed and water were offered ad libitum and artificial light was provided ( $23 \mathrm{~h}$ day) allover the experimental period. Chicks of the two experiments were kept under similar hygienic and environmental conditions. Composition and calculated analysis of the experimental diets are shown in Table (1); the Temperature-Humidity Index (THI) was calculated using the following formula (World Meteorological Organization (W.M.O), 1996), to determine the level of stress by using the Table (2) which explained Temperature Humidity index ranges and their corresponding stress categories (Smith et al., 1998).

$T H I=T_{d}-[0.55-(0.55 * R H / 100)] *\left(T_{d}-58\right)$.

Where; 
THI = Temperature Humidity Index;

$\mathrm{T}_{\mathrm{d}}=$ dry bulb temperature in degrees Fahrenheit;

$\mathrm{RH}=$ relative humidity $(\%)$.

Table (1). Composition and calculated analysis of the experimental diets.

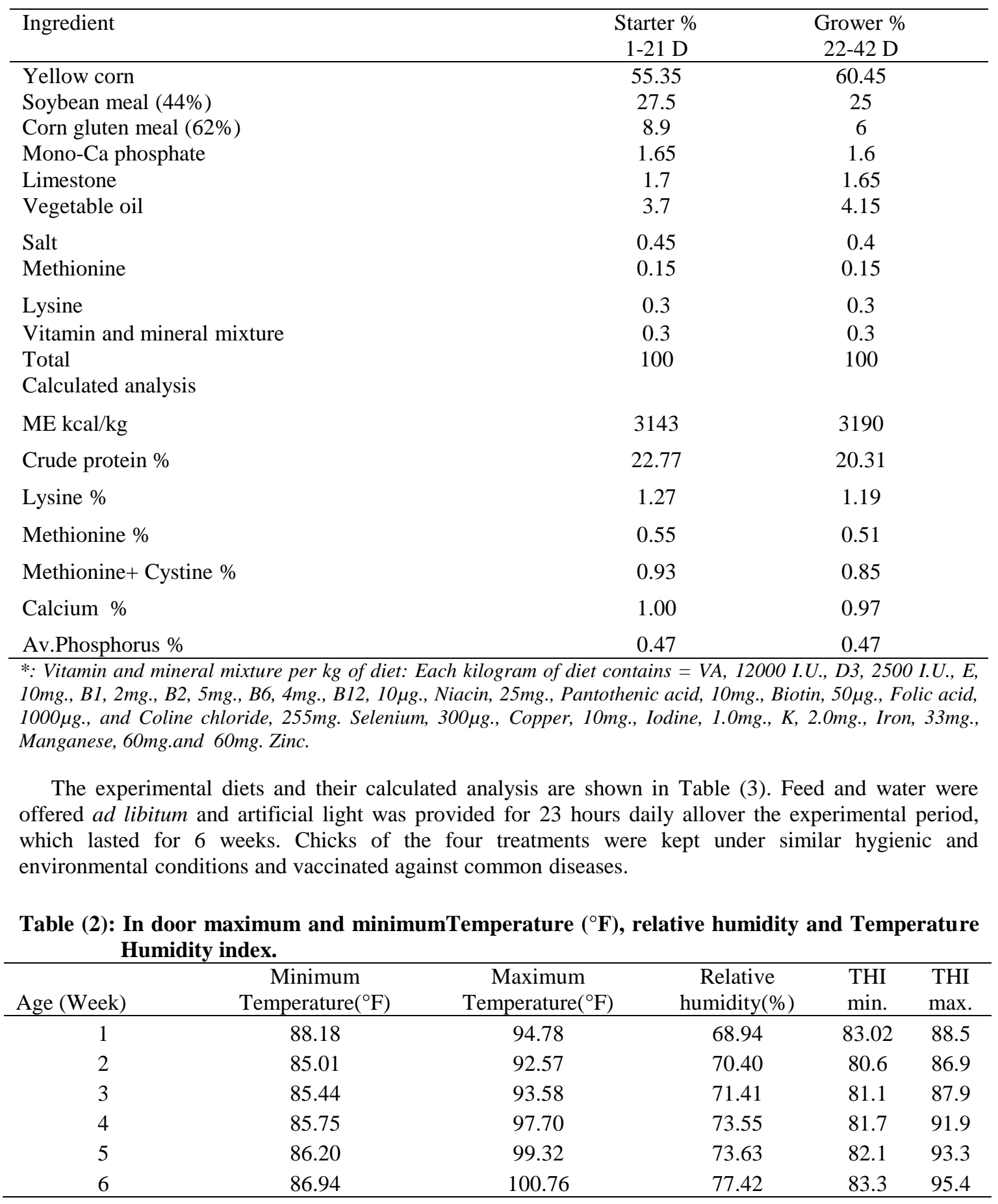

Table (3): Temperature Humidity index ranges and their corresponding stress categories.

\begin{tabular}{lc}
\hline Stress Category & THI range (inclusive) \\
\hline No stress & $<72$ \\
Mild stress & $72-79$ \\
Heat stress & $80-89$ \\
Severe stress & $90-98$ \\
Death & $>99$ \\
\hline
\end{tabular}




\section{Measurements}

Chicks were weighed at 1, 21 and 42 days of age (DOA). Body weight (BW) was recorded to the nearest $0.1 \mathrm{~g}$. The average body weight gain (BWG) was calculated by subtracting the average of initial body weight of the birds in a certain stage from the final one in the same stage. Feed intake was recorded to the nearest $0.1 \mathrm{~g}$ and then the feed conversion ratio (FCR) was calculated as gram feed to gram body weight gain.

Blood samples were collected from birds at 21 and 42 DOA during their exanguination into Waserman plastic tubes and Hemoglobin $(\mathrm{Hb})$, hematocrit $(\mathrm{HT})$, red blood cell count (RBSc), hemoglobin mean corpuscular hemoglobin ( $\mathrm{MCH})$, mean corpuscular hemoglobin concentration (MCHC), hemoglobin mean corpuscular volume (MCV) and heterophils to lymphocytes ratios (H/l ratio).

Hemoglobin $(\mathrm{Hb})$ values as $\mathrm{g} / 100 \mathrm{ml}$. of whole blood were determined by cyanomethemoglobin method using commercial kit purchased from Spectrum Diagnostics Cairo, Egypt, as described by Tietz (1990). Red blood cell count (RBSc) were performed by the method described by Natt and Herrick (1952), The blood samples were pipetted in heparinized microhematocrite tubes, centrifuged at 3000 r.p.m for 15 minutes and the hematocrite $(\mathrm{Ht})$ percent was recorded, hemoglobin mean corpuscular hemoglobin $(\mathrm{MCH})$, mean corpuscular hemoglobin concentration (MCHC), hemoglobin mean corpuscular volume (MCV), were calculated depended on $\mathrm{Hb}$, RBSc and Ht. Blood smears were also done, stained with Wright's stain procedure and used to calculate the number of lymphocytes $(\mathrm{L})$ and heterophils $(\mathrm{H})$ in 100 white blood cells, and then the $\mathrm{H} / \mathrm{L}$ ratio was calculated.

At the end of period (42 day of age), three birds from each treatment group were randomly taken, weighed and slaughtered. Feathers were manually removed and eviscerated, weights of Carcass, thigh, breast, liver, heart, gizzard and abdominal fat were also recorded to the nearest 1 gram and thymus, bersa and spleen were weighted and recorded to the nearest 0.01 gram.

Statistical analysis for all measured parameters was performed using the general linear model (GLM) produced by the Statistical Analysis Systems Institute (SAS, 2009).

\section{RESULTS AND DISCUSSION}

\section{Productive performance}

Results concerning the effect of different treatments on body weight BW and body weight gain BWG at 21 and 42 DOA of broiler chicks are illustrated in Table (4). Significant treatment differences $(\mathrm{P}<0.05)$ in favor of early age heat conditioning, were recorded for both final BW and BWG at 21 and 42 DOA compared with the non heat conditioning group. Concerning dietary supplements, the present data show that there were significant $(\mathrm{P}<0.05)$ increases effect in $\mathrm{BW}$ and $\mathrm{BWG}$ at 21 and $42 \mathrm{DOA}$. The best $\mathrm{BW}$ and BWG values were recorded for the vitamin $\mathrm{E}+$ organic selenium followed by vitamin $\mathrm{E}+$ organic chromium and then vitamin $\mathrm{E}+$ organic selenium+ organic chromium compared with the control. It appears from these results that Vit.E plus $\mathrm{Se}$ or $\mathrm{Cr}$ could act synergistically to stimulate factors that enhance growth performance of broilers. The effect of interaction among dietary supplements and early age heat conditioning was also significant for both BW and BWG with the best values recorded for Vit.E + Se and Vit.E + Cr under early age heat conditioning at the final stage of the experiment (42 DOA). The effect of different treatments on feed intake and feed conversion ratio are presented in Table 5. It is generally observed that, regardless supplements, feed intake was significantly $(\mathrm{P}<0.05)$ increased in the heat conditioning groups than non-heat treated ones at periods from 1 to $21 \mathrm{DOA}, 21$ to 42 and 1 to 42 DOA. A similar trend was obtained for dietary supplements groups, which showed that there were significant $(\mathrm{P}<0.05)$ differences in feed intake at periods from 1 to $21 \mathrm{DOA}, 21$ to 42 and 1 to 42 DOA. Dietary supplementation with Vit.E and Se increased feed intake of chicks with a similar increase in Vit.E and $\mathrm{Cr}$ group during the whole experiment period. Concerning feed conversion ratio, the present data illustrated that, there were insignificant effect of early age heat conditioning on feed conversion ratio during the period from 1 to $21 \mathrm{DOA}$, however this effect was significant during the periods from 21 to 42 
and 1 to 42 DOA. Concerning dietary supplements, the present data show that there were significant treatment $(\mathrm{P}<0.05)$ effects on feed conversion ratio at 1-21 DOA, 21-42 and 1-42 DOA. The best FC ratio was recorded for birds fed the dietary supplements compared with control. The interaction between early heat conditioning and dietary supplements was significant $(\mathrm{P}<0.05)$ for the studied periods. The improvement in productive performance was more obvious when dietary supplements is combined with early age heat conditioning by exposing chicks to $40 \pm 1^{\circ} \mathrm{C}$ for $24 \mathrm{~h}$ at $5 \mathrm{DOA}$. It is clear from the results that Vit.E supplements, showed the greatest improvement in the production performance of broilers. This was also observed in the early age heat conditioning chicks. This may be due to the role of Vit.E in alleviating the negative effects of heat stress on productive performance of birds. Since, the present exp. was done during the hottest months of summer season. The present results are in close agreement with Leshchinsky and Klasing, (2001); Siegel et al (2001); Sahin et al (2002) and Abdukalykova, and RuizFeria (2006), who reported positive effects of Vit.E on productive performance of different avian species. However, other workers found that Vit.E had no effect on productive performance traits (Amiri et al 2006; Boa-Amponsem, et al 2006 and Biswas et al 2007).

The role of organic Se in enhancing the productive performance of broilers may be related to its role in improving Insulin- Growth factors bioactivity (Moreno et al 2001) modulation of somatic growth and thyroid gland activity and improving nutrients metabolism (Surai, 2006; Jiang et al., 2009; Hanafy et al., 2009 and El-Sheikh et al., 2010 ). In this respect, Helmersson et al., (2005) reported a positive correlation between Se levels and IGF-I and some seleno enzymes, activity. However, some investigators have reported that organic Se supplementation did not affect body weight and daily gain of broilers (Patton et al, 2002 and Spears et al 2003) but Sahin et al., (2008) found that Se addition to quail diets increased body weight under heat stress conditions.

The beneficial effects of $\mathrm{Cr}$ supplementation to poultry diets was explained by its essential in potentiating the action of insulin through the presence of $\mathrm{Cr}$ in the glucose tolerance factor and activating some enzymes and stabilizing proteins and nuclic acids (Sahin et al 2001).

Concerning early age heat conditioning, results reflect the capability of birds to compensate for growth retardation (associated with heat stress) by different means including physiological and endocrinological mechanisms. It may be the hypothalamic set point of body temperature was changed by increasing the threshold core-temperature for heat production and/or heat loss, since the potential of thermotolerance can thus be improved. It is hypothesized that early age stressors (heat, malnutrition, disease, vaccination.... etc) are associated with some responses including growth retardation followed by long term compensatory growth which resulted in higher BW coincided with higher feed intake and improvement in feed conversion ratio. These results are in close agreement with those reported by Zulkifli, et al. (2002) and El-Moniary et al. (2010).

The combined effect of both Se; Vit.E and early age heat conditioning was more effective in improving productive performance under the prevalent experimental conditions. Since Se is involved in the recycling of Vit.E through the seleno-enzyme thioredoxin reductase, which recycles ascorbic acid and, in turn, promotes the recycling of Vit.E (Surai, 2002; Surai, 2006; Skřivan et al., 2008).

\section{Hematological parameters}

Results concerning the effect of early age heat conditioning and some dietary supplements on hemoglobin $(\mathrm{Hb})$, hematocrit $(\mathrm{HT})$, red blood cell count (RBC'S), mean corpuscular hemoglobin $(\mathrm{MCH})$, mean corpuscular hemoglobin concentration (MCHC), mean corpuscular volume (MCV) and heterophils to lymphocytes ratios (H/L ratio), are presented in Tables (6 and 7). It is clear that early heat conditioning of broiler chicks at 5 DOA has significantly improved their hematological parameters at 21 DOA (Table 6). At 42 day of age the same trend was observed where early heat conditioning had significant $(\mathrm{P}<0.05)$ effects on Hb, HT, and RBC'S levels, however MCH, MCHC and MCV values did not significantly affected. Concerning dietary supplements; regardless heat conditioning, the present data show significant effects of feed supplements on the overall mean of the hematological parameters, where there were significant increases in $\mathrm{Hb}, \mathrm{Ht}, \mathrm{RBC}$ 'S, MCH, MCHC and MCV values at 21 day of age (Table 6), at 42 DOA except for $\mathrm{MCH}, \mathrm{MCHC}$ and $\mathrm{MCV}$ which were not significant (Table 7). The interaction between early age heat conditioning and dietary supplements on hematological parameters was significant $(\mathrm{P}<0.05)$ at 21 and $42 \mathrm{DOA}$ except the $\mathrm{MCH}$ and $\mathrm{MCHC}$ values which were insignificant at $42 \mathrm{DOA}$. Results showed also that early age heat conditioning of broiler chicks has a significant effect on $\mathrm{H} / \mathrm{L}$ ratio either at 21 or 42 DOA (Table 6 and 7) with the lowest ratio being recorded for HC chicks. This was not the case for the influence of dietary treatments on the $\mathrm{H} / \mathrm{L}$ ratio at the same ages. However, the interaction between $\mathrm{HC}$ and dietary supplements was significant with the lower ratios for HC group compared with the NHC treatment. It is clear from the present results that dietary supplements and early age heat conditioning treatment improved the hematological parameters of chicks. This response was also observed for chicks of the early age heat conditioning regardless the dietary supplements. This technique 


\section{Gouda et al.}

was approved as a sensitive process to induce thermotolerance at an early age of broiler (3-5 days). In this respect many researches proposed early age heat conditioning as a management technique to reinforce the resistance of broiler chicks to acute heat stress or sudden heat spells during finishing period (Yahav et al., 2004 and 2005; Ali and Hossain, 2010; El-Wardany et al., 2012 and Hemid et al., 2013).

The present results are in agreement with those Ahmed and Reddy (2012); El-Moniary et al., (2010) and Hemid et al., (2013), who found that the hematological responses to acute or chronic heat stress include changes in RBC'S count, $\mathrm{Hb}$ and Ht levels and leucocytes differential count, especially heterophils and lymphocytes.

Muller., (2010) found that vitamin E and selenium, improved the blood parameters where vitamin E works to protect phospholipids of cellular and sub cellular membranes, by preventing the oxidation of fatty acids. This antioxidant effect of vitamin $\mathrm{E}$ is efficient in high concentrations of oxygen and therefore is concentrated in red blood cells and membranes.

Data showed that, hemoglobin level was decreased significantly and hematocrit tended to increase in broilers fed supplemental Cr. Wilson (1971) reported that some hematology parameter (i.e. Hb; Ht;...) may be used to diagnose both quantitative and morphologic physiological alterations that might be associated with heat stress. According to Kubena et al. (1972) exposure of chickens to high temperatures causes a increase in blood hematocrit and hemoglobin values. In addition Toghyani et al; (2006) reported that $\mathrm{Cr}$ supplementation increased hematocrit of stressed animal.

There is evidence that both Vit.E and Se plays a major role in protecting living cells from damage and this protection was achieved via better and healthy hematological and immunological responses, which is the case in the present study. This holds true as Surai, (2002 and 2006) stated that Se deficiency in chickens, especially when combiened with low Vit.E supply, is responsible for a range of diseases due to mal function of different organs. It may be also that Se can improve nutrients utilization due to its antioxidant properties which protect nutrients and vitamins (fat- soluble vitamins) from oxidation. This was proved by (Yang, et al 2012).

\section{Carcass characteristics and some organs weight}

The overall means of carcass weight $(\%)$ and the relative weights of some body organs are presented in Tables $(8$ and 9$)$. It is clear that early age heat conditioning had significantly $(\mathrm{P}<0.05)$ increased the relative weights of carcass; breast; thigh; gizzard; heart; abdominal fat and thymus gland with an insignificant effect on bursa of Fabricius and spleen. However, liver (\%) was significantly decreased. Concerning dietary supplements, results showed the relative weight of carcass; breast muscles; thigh; gizzard and heart were significantly increased, regardless early age heat conditioning treatment. On the other hand, the relative weight of liver was significantly $(\mathrm{P}<0.05)$ decreased by dietary supplements. Moreover, the relative weights of abdominal fat; bursa; thymus and spleen were not significantly affected. The interaction effect between early age heat conditioning and dietary supplements on studied traits was significant except for the lymphoid organs. The results indicate that dietary supplements have well improved carcass characteristics, and this may be due to that broilers are able to compensate the retardation of growth by different magnitudes including the well documented relationships between the dietary supplements and some endocrine functions which include the stimulatory effects of Vit.E; Se and $\mathrm{Cr}$. on thyroid gland activity insulin hormone production under heat stress conditions. In accordance with the results of the performance data in the present study it has been suggested that caracass trait were also affected by different feed supplements may regulate some endocrienal function and acts as antioxidants which in turn protect dietary nutrents and body tissue from oxidative stress. These results are consistent with Yahav et al., (1997); Yahav and Plavink (1999); Sahin et al., (2002); and Surai (2002).

In the present study $\mathrm{Cr}$ supplementation has insignificant effect on abdominal fat which in agreement with the result of Lien et al. (1999), but is in incoherence with those of Ward et al. (1993), Hossain et al. (1998) and Sahin et al. (2003). They may be due to the role played by $\mathrm{Cr}$ in insulin secration and its metabolic effects.

Concerning early age heat conditioning of chicks, showed body and breast muscle weights were greater in heat conditioning chicks vs. their untreated counterparts at later ages which confirm the results of Yahav (1998 and 2000) and Yahav and Hurwitz (1996). The present results focused on the early events of postnatal skeletal muscle development that lead to enhanced hypertrophy at later ages. The results showed for the first time that mild heat exposure, at an early age has a stimulatory effect on skeletal muscle growth due to an immediate increase in satellite cell proliferation followed by accelerated differentiation, this support the findings by Yahav et al., (2004); El-Moniary et al., (2010); and Hemid et al., (2013). 
Table (4). Effect of some dietary supplements and early age heat conditioning on Body weight (BW) and body weight gain (BWG) of broiler chicks at different ages.

\begin{tabular}{|c|c|c|c|c|c|c|}
\hline \multirow{2}{*}{$\begin{array}{ll} & \text { Trait } \\
\text { Treatment } & \end{array}$} & \multicolumn{3}{|c|}{$\mathrm{BW}(\mathrm{g})$} & \multicolumn{3}{|c|}{ BWG (g) } \\
\hline & $1 \mathrm{DOA}$ & $21 \mathrm{DOA}$ & $42 \mathrm{DOA}$ & 1-21 DOA & 21-42 DOA & $1-42 \mathrm{DOA}$ \\
\hline \multicolumn{7}{|l|}{ Heat conditioning $(\mathrm{HC})$ : } \\
\hline Non heat conditioning (NHC) & $41.40 \pm 0.87$ & $604.3^{\mathrm{b}} \pm 60.43$ & $1830.8^{\mathrm{b}} \pm 138.30$ & $562.9^{\mathrm{b}} \pm 60.42$ & $1225.1^{\mathrm{b}} \pm 133.53$ & $1788.6^{\mathrm{b}} \pm 138.38$ \\
\hline Heat conditioning $(\mathrm{HC})$ & $41.26 \pm 1.05$ & $620.4^{\mathrm{a}} \pm 62.31$ & $1908.3^{; \mathrm{a}} \pm 129.49$ & $579.1^{\mathrm{a}} \pm 62.45$ & $1290.5^{\mathrm{a}} \pm 128.41$ & $1867.3^{\mathrm{a}} \pm 129.53$ \\
\hline Significance & NS & $*$ & $*$ & $*$ & $*$ & $*$ \\
\hline \multicolumn{7}{|l|}{ Dietary supplements $(\mathrm{T})$} \\
\hline Control & $41.41 \pm 0.87$ & $587.1^{\mathrm{b}} \pm 62.44$ & $1799.9^{b} \pm 131.13$ & $545.8^{\mathrm{b}} \pm 62.35$ & $1213.4^{\mathrm{b}} \pm 132.59$ & $1758.5^{\mathrm{b}} \pm 131.07$ \\
\hline Vit. $\mathrm{E}+\mathrm{Cr}$ & $41.37 \pm 0.91$ & $610.8^{\mathrm{a}} \pm 53.49$ & $1886.9^{\mathrm{a}} \pm 73.98$ & $564.4^{\mathrm{a}} \pm 53.66$ & $1279.7^{\mathrm{a}} \pm 87.20$ & $1845.5^{\mathrm{a}} \pm 74.07$ \\
\hline Vit. E+ Se & $41.27 \pm 1.03$ & $630.6^{\mathrm{a}} \pm 63.24$ & $1904.7^{\mathrm{a}} \pm 170.87$ & $589.3^{\mathrm{a}} \pm 63.39$ & $1273.2^{\mathrm{a}} \pm 167.04$ & $1863.5^{\mathrm{a}} \pm 170.98$ \\
\hline Vit. $\mathrm{E}+\mathrm{Cr}+\mathrm{Se}$ & $41.27 \pm 1.05$ & $620.9^{\mathrm{a}} \pm 60.39$ & $1885.8^{\mathrm{a}} \pm 141.87$ & $579.6^{\mathrm{a}} \pm 60.43$ & $1264.9^{\mathrm{a}} \pm 133.38$ & $1844.4^{\mathrm{a}} \pm 142.02$ \\
\hline Significance & NS & $*$ & $*$ & $*$ & $*$ & $*$ \\
\hline \multicolumn{7}{|l|}{ interaction } \\
\hline \multicolumn{7}{|l|}{ A-Non heat conditioning $(\mathrm{NHC}) \times$} \\
\hline Control & $41.37 \pm 0.82$ & $576.2^{\mathrm{d}} \pm 55.81$ & $1750.9^{c} \pm 138.77$ & $534.8^{d} \pm 55.55$ & $1175.9^{c} \pm 136.89$ & $1709.5^{c} \pm 138.86$ \\
\hline Vit. $\mathrm{E}+\mathrm{Cr}$ & $41.37 \pm 0.86$ & $614.2^{\mathrm{abc}} \pm 62.47$ & $1849.8^{\mathrm{b}} \pm 78.30$ & $572.8^{a b c} \pm 62.56$ & $1240.4^{\mathrm{abc}} \pm 85.98$ & $1808.3^{\mathrm{b}} \pm 78.44$ \\
\hline Vit. E+ Sel & $41.37 \pm 1.01$ & $631.4^{\mathrm{ab}} \pm 57.38$ & $1867.8^{\mathrm{ab}} \pm 155.90$ & $590^{\mathrm{ab}} \pm 57.57$ & $1231.0^{\mathrm{bc}} \pm 146.40$ & $1826.4^{\mathrm{ab}} \pm 155.82$ \\
\hline Vit. $\mathrm{E}+\mathrm{Cr}+\mathrm{Sel}$ & $41.48 \pm 0.82$ & $595.4^{\mathrm{cd}} \pm 54.11$ & $1851.9^{\mathrm{b}} \pm 142.09$ & $553.9^{\mathrm{cd}} \pm 54.08$ & $1253^{\mathrm{abc}} \pm 149.30$ & $1810.4^{\mathrm{b}} \pm 142.42$ \\
\hline \multicolumn{7}{|l|}{ B- heat conditioning $(\mathrm{HC}) \times$} \\
\hline Control & $41.44 \pm 0.94$ & $598.2^{\mathrm{bcd}} \pm 67.61$ & $1849^{b} \pm 103.95$ & $556.7^{\mathrm{bcd}} \pm 67.70$ & $1250.8^{\mathrm{abc}} \pm 119.21$ & $1807.5^{b} \pm 103.76$ \\
\hline Vit. $\mathrm{E}+\mathrm{Cr}$ & $41.37 \pm 0.97$ & $607.3^{\mathrm{bcd}} \pm 43.56$ & $1924.9^{\mathrm{ab}} \pm 46.48$ & $565.9^{\mathrm{bcd}} \pm 43.86$ & $1319.0^{\mathrm{a}} \pm 70.03$ & $1882.6^{\mathrm{ab}} \pm 46.53$ \\
\hline Vit. E+ Sel & $41.17 \pm 1.07$ & $629.8^{\mathrm{ab}} \pm 69.64$ & $1941.7^{\mathrm{a}} \pm 180.06$ & $588.6^{\mathrm{ab}} \pm 69.74$ & $1315.4^{\mathrm{a}} \pm 178.29$ & $1900.5^{\mathrm{a}} \pm 180.26$ \\
\hline Vit. $\mathrm{E}+\mathrm{Cr}+\mathrm{Sel}$ & $41.06 \pm 1.22$ & $646.3^{\mathrm{a}} \pm 56.17$ & $1919.5^{\mathrm{ab}} \pm 135.98$ & $605.2^{\mathrm{a}} \pm 56.11$ & $1276.7^{\mathrm{ab}} \pm 117.10$ & $1878.4^{\mathrm{ab}} \pm 135.87$ \\
\hline Significance & NS & $*$ & $*$ & $*$ & $*$ & $*$ \\
\hline
\end{tabular}

$N S=$ non-significant, ${ }^{*}=P \leq 0.05$. 
Gouda et al.

Table (5). Effect of some dietary supplements and early age heat conditioning on feed intake (FI) and Feed conversion ratio (F.C) of broiler chicks at different ages.

\begin{tabular}{|c|c|c|c|c|c|c|}
\hline \multirow[b]{2}{*}{ Treatment } & \multicolumn{3}{|c|}{ FI (g) } & \multicolumn{3}{|c|}{ FC ratio } \\
\hline & $1-21 \mathrm{DOA}$ & $21-42 \mathrm{DOA}$ & $1-42 \mathrm{DOA}$ & $1-21 \mathrm{DOA}$ & $21-42 \mathrm{DOA}$ & 1-42 DOA \\
\hline \multicolumn{7}{|l|}{ Heat conditioning $(\mathrm{HC})$ : } \\
\hline Non heat conditioning (NHC) & $798^{b} \pm 13.15$ & $2538^{\mathrm{b}} \pm 47.57$ & $3336^{\mathrm{b}} \pm 51.30$ & $1.41 \pm 0.148$ & $2.10^{\mathrm{a}} \pm 0.236$ & $1.88^{\mathrm{a}} \pm 0.144$ \\
\hline Heat conditioning $(\mathrm{HC})$ & $809^{\mathrm{a}} \pm 27.56$ & $2565^{\mathrm{a}} \pm 28.72$ & $3374^{\mathrm{a}} \pm 39.35$ & $1.43 \pm 0.148$ & $2.01^{\mathrm{b}} \pm 0.199$ & $1.81^{\mathrm{b}} \pm 0.120$ \\
\hline Significance & $*$ & $*$ & $*$ & NS & $*$ & $*$ \\
\hline \multicolumn{7}{|l|}{ Dietary supplements $(\mathrm{T})$} \\
\hline Control & $799^{b} \pm 28.73$ & $2543^{\mathrm{b}} \pm 38.28$ & $3342^{b} \pm 55.05$ & $1.48^{\mathrm{a}} \pm 0.171$ & $2.12^{\mathrm{a}} \pm 0.240$ & $1.91^{\mathrm{a}} \pm 0.146$ \\
\hline Vit. $\mathrm{E}+\mathrm{Cr}$ & $799^{\mathrm{b}} \pm 18.02$ & $2561^{\mathrm{a}} \pm 42.51$ & $3360^{\mathrm{ab}} \pm 44.43$ & $1.42^{\mathrm{b}} \pm 0.137$ & $2.01^{\mathrm{b}} \pm 0.150$ & $1.82^{\mathrm{b}} \pm 0.077$ \\
\hline Vit. E+ Se & $805^{\mathrm{ab}} \pm 14.07$ & $2560^{\mathrm{a}} \pm 30.86$ & $3365^{\mathrm{a}} \pm 32.0$ & $1.38^{\mathrm{b}} \pm 0.135$ & $2.04^{\mathrm{ab}} \pm 0.258$ & $1.82^{\mathrm{b}} \pm 0.154$ \\
\hline Vit. $\mathrm{E}+\mathrm{Cr}+\mathrm{Se}$ & $812^{\mathrm{a}} \pm 23.13$ & $2541^{\mathrm{b}} \pm 49.20$ & $3353^{\mathrm{ab}} \pm 59.37$ & $1.41^{\mathrm{b}} \pm 0.132$ & $2.03^{\mathrm{b}} \pm 0.218$ & $1.83^{\mathrm{b}} \pm 0.133$ \\
\hline $\begin{array}{l}\text { Significance } \\
\text { interaction }\end{array}$ & $*$ & $*$ & $*$ & $*$ & $*$ & $*$ \\
\hline \multicolumn{7}{|l|}{ A-Non heat conditioning $(\mathrm{NHC}) \times$} \\
\hline Control & $792^{c} \pm 8.05$ & $2520^{\mathrm{b}} \pm 35.18$ & $3311^{\mathrm{c}} \pm 40.34$ & $1.50^{\mathrm{a}} \pm 0.157$ & $2.17^{\mathrm{a}} \pm 0.260$ & $1.95^{\mathrm{a}} \pm 0.162$ \\
\hline Vit. $\mathrm{E}+\mathrm{Cr}$ & $796^{\mathrm{bc}} \pm 15.12$ & $2558^{\mathrm{a}} \pm 51.10$ & $3354^{\mathrm{b}} \pm 51.62$ & $1.40^{\mathrm{bc}} \pm 0.150$ & $2.07^{\mathrm{abc}} \pm 0.151$ & $1.86^{\mathrm{bc}} \pm 0.082$ \\
\hline Vit. $\mathrm{E}+\mathrm{Se}$ & $806^{b} \pm 15.28$ & $2551^{\mathrm{a}} \pm 36.0$ & $3358^{\mathrm{ab}} \pm 40.16$ & $1.38^{\mathrm{c}} \pm 0.124$ & $2.10^{\mathrm{ab}} \pm 0.255$ & $1.85^{b c} \pm 0.153$ \\
\hline Vit. $\mathrm{E}+\mathrm{Cr}+\mathrm{Se}$ & $799^{\mathrm{bc}} \pm 8.01$ & $2523^{\mathrm{b}} \pm 54.8$ & $3323^{c} \pm 57.33$ & $1.46^{\mathrm{abc}} \pm 0.137$ & $2.04^{\mathrm{abc}} \pm 0.256$ & $1.85^{\mathrm{bc}} \pm 0.146$ \\
\hline \multicolumn{7}{|l|}{ B- heat conditioning $(\mathrm{HC}) \times$} \\
\hline Control & $806^{b} \pm 38.88$ & $2567^{\mathrm{a}} \pm 24.07$ & $3373^{\mathrm{ab}} \pm 50.51$ & $1.47^{\mathrm{ab}} \pm 0.184$ & $2.07^{\mathrm{abc}} \pm 0.213$ & $1.87^{\mathrm{b}} \pm 0.118$ \\
\hline Vit. $\mathrm{E}+\mathrm{Cr}$ & $803^{b c} \pm 20.20$ & $2565^{\mathrm{a}} \pm 32.42$ & $3366^{\mathrm{ab}} \pm 35.78$ & $1.47^{\mathrm{ab}} \pm 0.123$ & $1.95^{\mathrm{c}} \pm 0.124$ & $1.79^{c} \pm 0.056$ \\
\hline Vit. E+ Se & $803^{\mathrm{bc}} \pm 12.80$ & $2568^{\mathrm{a}} \pm 21.96$ & $3.372^{\mathrm{ab}} \pm 19.47$ & $1.38^{\mathrm{c}} \pm 0.147$ & $1.98^{\mathrm{bc}} \pm 0.252$ & $1.79^{\mathrm{c}} \pm 0.152$ \\
\hline Vit. $\mathrm{E}+\mathrm{Cr}+\mathrm{Se}$ & $825^{\mathrm{a}} \pm 26.58$ & $2560^{\mathrm{a}} \pm 35.17$ & $3383^{\mathrm{a}} \pm 44.87$ & $1.37^{\mathrm{c}} \pm 0.115$ & $2.02^{b c} \pm 0.175$ & $1.81^{b c} \pm 0.119$ \\
\hline Significance & $*$ & $*$ & $*$ & $*$ & $*$ & $*$ \\
\hline
\end{tabular}

${ }_{a, b, c}$ Means $\pm S D$ within a column with different superscripts are significantly different $(P \leq 0.05)$.

$N S=$ non-significant,$*=P \leq 0.05$. 
Egyptian J. Nutrition and Feeds (2017), 20 (2) Special Issue

Table (6). Effect of some dietary supplements and early age heat conditioning on hematological parameters of broiler chicks at 21 DOA.

\begin{tabular}{|c|c|c|c|c|c|c|c|}
\hline Trait (21 DOA) & $\begin{array}{c}\mathrm{Hb} \\
(\mathrm{g} / 100 \mathrm{ml}) \\
\end{array}$ & $\begin{array}{l}\mathrm{Ht} \\
(\%)\end{array}$ & $\mathrm{RBC}^{\prime} \mathrm{S}\left(10^{6} / \mathrm{mm}^{3}\right)$ & $\begin{array}{l}\mathrm{MCH} \\
(\mathrm{pg} / \mathrm{dl}) \\
\end{array}$ & $\begin{array}{c}\mathrm{MCHC} \\
(\%)\end{array}$ & $\begin{array}{l}\text { MCV } \\
\left(\mu \mathrm{m}^{3}\right) \\
\end{array}$ & $\mathrm{H} / \mathrm{L}$ ratio \\
\hline \multicolumn{8}{|l|}{ Heat conditioning $(\mathrm{HC})$ : } \\
\hline Non heat conditioning (NHC) & $8.79^{\mathrm{b}} \pm 0.96$ & $34.01^{\mathrm{b}} \pm 0.75$ & $3.01^{\mathrm{b}} \pm 0.26$ & $28.78 \pm 0.56$ & $25.83^{\mathrm{b}} \pm 2.48$ & $105.03^{\mathrm{b}} \pm 9.01$ & $0.59^{\mathrm{a}} \pm 0.026$ \\
\hline Heat conditioning $(\mathrm{HC})$ & $9.87^{\mathrm{a}} \pm 0.58$ & $35.76^{\mathrm{a}} \pm 1.45$ & $3.43^{\mathrm{a}} \pm 0.087$ & $29.18 \pm 1.61$ & $27.59^{\mathrm{a}} \pm 1.02$ & $112.9^{\mathrm{a}} \pm 4.75$ & $0.51^{\mathrm{b}} \pm 0.031$ \\
\hline Significance & $*$ & $*$ & $*$ & NS & $*$ & $*$ & $*$ \\
\hline \multicolumn{8}{|l|}{ Dietary supplements $(\mathrm{T})$} \\
\hline Control & $8.55^{\mathrm{b}} \pm 0.49$ & $34.05^{\mathrm{b}} \pm 1.43$ & $3.06^{\mathrm{b}} \pm 0.13$ & $27.91^{\mathrm{b}} \pm 0.39$ & $25.10^{\mathrm{b}} \pm 0.92$ & $111.30^{\mathrm{ab}} \pm 4.08$ & $0.57 \pm 0.049$ \\
\hline Vit. $\mathrm{E}+\mathrm{Cr}$ & $8.73^{b} \pm 0.43$ & $34.20^{\mathrm{b}} \pm 1.45$ & $3.03^{\mathrm{b}} \pm 0.16$ & $28.80^{\mathrm{ab}} \pm 0.77$ & $25.53^{b} \pm 0.78$ & $112.86^{\mathrm{a}} \pm 3.82$ & $0.55 \pm 0.057$ \\
\hline Vit. $\mathrm{E}+\mathrm{Se}$ & $9.96^{\mathrm{a}} \pm 0.79$ & $35.56^{\mathrm{a}} \pm 0.88$ & $3.37^{\mathrm{a}} \pm 0.31$ & $29.55^{\mathrm{a}} \pm 1.30$ & $28.00^{\mathrm{a}} \pm 1.88$ & $105.88^{\mathrm{b}} \pm 8.04$ & $0.54 \pm 0.044$ \\
\hline Vit. $\mathrm{E}+\mathrm{Cr}+\mathrm{Se}$ & $10.08^{\mathrm{a}} \pm 0.90$ & $35.75^{\mathrm{a}} \pm 1.33$ & $3.41^{\mathrm{a}} \pm 0.44$ & $29.66^{\mathrm{a}} \pm 1.36$ & $28.20^{\mathrm{a}} \pm 2.27$ & $106.00^{\mathrm{b}} \pm 12.7$ & $0.54 \pm 0.044$ \\
\hline \multicolumn{8}{|l|}{ interaction } \\
\hline \multicolumn{8}{|l|}{ A-Non heat conditioning $(\mathrm{NHC}) \times$} \\
\hline Control & $8.20^{\mathrm{d}} \pm 0.45$ & $32.83^{\mathrm{b}} \pm 0.64$ & $2.97^{\mathrm{bc}} \pm 0.120$ & $27.60^{\mathrm{c}} \pm 0.13$ & $24.97^{\mathrm{b}} \pm 1.39$ & $110.55^{\mathrm{a}} \pm 6.30$ & $0.61^{\mathrm{a}} \pm 0.040$ \\
\hline Vit. $\mathrm{E}+\mathrm{Cr}$ & $8.40^{\mathrm{cd}} \pm 0.15$ & $32.90^{\mathrm{b}} \pm 0.43$ & $2.94^{\mathrm{c}} \pm 0.025$ & $28.52^{b c} \pm 0.35$ & $25.53^{\mathrm{b}} \pm 0.51$ & $111.82^{\mathrm{a}} \pm 0.95$ & $0.59^{\mathrm{a}} \pm 0.020$ \\
\hline Vit. E+ Se & $9.26^{\mathrm{b}} \pm 0.20$ & $35.0^{\mathrm{a}} \pm 0.11$ & $3.10^{\mathrm{bc}} \pm 0.040$ & $29.93^{\mathrm{ab}} \pm 0.81$ & $26.49^{\mathrm{b}} \pm 0.66$ & $112.94^{\mathrm{a}} \pm 0.86$ & $0.58^{\mathrm{ab}} \pm 0.030$ \\
\hline Vit. $\mathrm{E}+\mathrm{Cr}+\mathrm{Se}$ & $9.30^{\mathrm{b}} \pm 0.15$ & $35.33^{\mathrm{a}} \pm 1.25$ & $3.03^{b c} \pm 0.081$ & $30.67^{\mathrm{a}} \pm 0.33$ & $26.32^{\mathrm{b}} \pm 1.36$ & $116.65^{\mathrm{a}} \pm 3.93$ & $0.58^{\mathrm{ab}} \pm 0.015$ \\
\hline \multicolumn{8}{|l|}{ B- heat conditioning $(\mathrm{HC}) \times$} \\
\hline Control & $8.90^{\mathrm{bc}} \pm 0.20$ & $35.26^{\mathrm{a}} \pm 0.55$ & $3.15^{\mathrm{b}} \pm 0.020$ & $28.22^{\mathrm{bc}} \pm 0.28$ & $25.24^{\mathrm{b}} \pm 0.35$ & $112.05^{\mathrm{a}} \pm 0.54$ & $0.53^{b c} \pm 0.010$ \\
\hline Vit. $\mathrm{E}+\mathrm{Cr}$ & $9.06^{\mathrm{b}} \pm 0.34$ & $35.50^{\mathrm{a}} \pm 0.10$ & $3.11^{b c} \pm 0.032$ & $29.09^{\mathrm{abc}} \pm 1.06$ & $25.54^{\mathrm{b}} \pm 1.12$ & $113.90^{\mathrm{a}} \pm 5.68$ & $0.52^{c} \pm 0.064$ \\
\hline Vit. E+ Se & $10.66^{\mathrm{a}} \pm 0.25$ & $36.13^{\mathrm{a}} \pm 0.10$ & $3.65^{\mathrm{a}} \pm 0.100$ & $29.17^{\mathrm{abc}} \pm 1.77$ & $29.52^{\mathrm{a}} \pm 1.25$ & $98.82^{b} \pm 3.39$ & $0.51^{\mathrm{c}} \pm 0.015$ \\
\hline Vit. $\mathrm{E}+\mathrm{Cr}+\mathrm{Se}$ & $10.86^{\mathrm{a}} \pm 0.43$ & $36.16^{\mathrm{a}} \pm 1.52$ & $3.79^{\mathrm{a}} \pm 0.152$ & $28.64^{b c} \pm 1.19$ & $30.07^{\mathrm{a}} \pm 0.71$ & $95.36^{\mathrm{b}} \pm 6.99$ & $0.50^{\mathrm{c}} \pm 0.015$ \\
\hline Significance & $*$ & $*$ & $*$ & $*$ & $*$ & $*$ & $*$ \\
\hline
\end{tabular}

$a, b, c$
$N S=$ Mons \pm significant, $*=P \leq 0.05$.

Table (7). Effect of some dietary supplements and early age heat conditioning on hematological parameters of broiler chicks at 42 DOA. 
Gouda et al.

\begin{tabular}{|c|c|c|c|c|c|c|c|}
\hline Trait (42 DOA) & $\begin{array}{c}\mathrm{Hb} \\
(\mathrm{g} / 100 \mathrm{ml})\end{array}$ & $\begin{array}{l}\mathrm{Ht} \\
(\%)\end{array}$ & $\begin{array}{c}\text { RBC'S } \\
\left(10^{6} / \mathrm{mm}^{3}\right)\end{array}$ & $\begin{array}{l}\mathrm{MCH} \\
(\mathrm{pg} / \mathrm{dl})\end{array}$ & $\begin{array}{c}\mathrm{MCHC} \\
(\%)\end{array}$ & $\begin{array}{l}\mathrm{MCV} \\
\left(\mu \mathrm{m}^{3}\right)\end{array}$ & $\mathrm{H} / \mathrm{L}$ ratio \\
\hline \multicolumn{8}{|l|}{ Heat conditioning $(\mathrm{HC})$ : } \\
\hline Non heat conditioning (NHC) & $10.93^{\mathrm{b}} \pm 0.46$ & $29.90^{\mathrm{b}} \pm 0.90$ & $3.30^{\mathrm{b}} \pm 0.27$ & $31.77 \pm 2.32$ & $36.54 \pm 1.43$ & $90.56 \pm 5.27$ & $0.61^{\mathrm{a}} \pm 0.026$ \\
\hline Heat conditioning $(\mathrm{HC})$ & $11.47^{\mathrm{a}} \pm 0.56$ & $31.60^{\mathrm{a}} \pm 1.09$ & $3.62^{\mathrm{a}} \pm 0.10$ & $33.10 \pm 1.27$ & $36.32 \pm 1.05$ & $87.47 \pm 1.77$ & $0.53^{\mathrm{b}} \pm 0.031$ \\
\hline Significance & $*$ & $*$ & $*$ & NS & NS & NS & $*$ \\
\hline \multicolumn{8}{|l|}{ Dietary supplements $(\mathrm{T})$} \\
\hline Control & $10.73^{\mathrm{b}} \pm 0.46$ & $29.83^{\mathrm{b}} \pm 0.90$ & $3.32^{\mathrm{b}} \pm 0.13$ & $32.25 \pm 0.79$ & $35.98 \pm 1.28$ & $89.70 \pm 3.01$ & $0.59 \pm 0.049$ \\
\hline Vit. $\mathrm{E}+\mathrm{Cr}$ & $10.80^{\mathrm{b}} \pm 0.37$ & $30.20^{\mathrm{b}} \pm 1.45$ & $3.36^{\mathrm{ab}} \pm 0.16$ & $32.08 \pm 0.63$ & $35.78 \pm 0.95$ & $89.66 \pm 1.16$ & $0.57 \pm 0.057$ \\
\hline Vit. E+ Se & $11.55^{\mathrm{a}} \pm 0.37$ & $31.40^{\mathrm{a}} \pm 0.88$ & $3.58^{\mathrm{a}} \pm 0.30$ & $32.37 \pm 2.37$ & $36.79 \pm 1.18$ & $87.96 \pm 5.27$ & $0.56 \pm 0.044$ \\
\hline Vit. $\mathrm{E}+\mathrm{Cr}+\mathrm{Se}$ & $11.73^{\mathrm{a}} \pm 0.30$ & $31.58^{\mathrm{a}} \pm 1.20$ & $3.57^{\mathrm{a}} \pm 0.33$ & $33.04 \pm 3.20$ & $37.17 \pm 1.21$ & $88.75 \pm 6.23$ & $0.56 \pm 0.044$ \\
\hline Significance & $*$ & $*$ & $*$ & NS & NS & NS & NS \\
\hline \multicolumn{8}{|l|}{ interaction } \\
\hline \multicolumn{8}{|l|}{ A-Non heat conditioning $(\mathrm{NHC}) \times$} \\
\hline Control & $10.40^{\mathrm{c}} \pm 0.37$ & $29.06^{\mathrm{c}} \pm 0.52$ & $3.22^{c} \pm 0.120$ & $32.23 \pm 0.72$ & $35.77 \pm 1.85$ & $90.08^{\mathrm{ab}} \pm 4.59$ & $0.63^{\mathrm{a}} \pm 0.040$ \\
\hline Vit. $\mathrm{E}+\mathrm{Cr}$ & $10.50^{c} \pm 0.10$ & $28.90^{\mathrm{c}} \pm 0.43$ & $3.22^{\mathrm{c}} \pm 0.015$ & $32.57 \pm 0.15$ & $36.33 \pm 0.61$ & $89.66^{\mathrm{ab}} \pm 1.40$ & $0.61^{\mathrm{a}} \pm 0.021$ \\
\hline Vit. E+ Se & $11.30^{\mathrm{b}} \pm 0.26$ & $30.66^{\mathrm{b}} \pm 0.11$ & $3.31^{\mathrm{c}} \pm 0.045$ & $34.17 \pm 0.78$ & $36.86 \pm 0.91$ & $92.67^{\mathrm{a}} \pm 0.78$ & $0.60^{\mathrm{ab}} \pm 0.031$ \\
\hline Vit. $\mathrm{E}+\mathrm{Cr}+\mathrm{Se}$ & $11.53^{\mathrm{ab}} \pm 0.15$ & $31.0^{\mathrm{ab}} \pm 1.25$ & $3.45^{\mathrm{bc}} \pm 0.47$ & $33.42 \pm 4.98$ & $37.20 \pm 1.90$ & $89.84^{\mathrm{ab}} \pm 9.49$ & $0.60^{\mathrm{ab}} \pm 0.015$ \\
\hline \multicolumn{8}{|l|}{ B- heat conditioning $(\mathrm{HC}) \times$} \\
\hline Control & $11.06^{\mathrm{b}} \pm 0.26$ & $30.60^{\mathrm{b}} \pm 0.15$ & $3.43^{b c} \pm 0.021$ & $32.27 \pm 1.02$ & $36.18 \pm 0.72$ & $89.32^{\mathrm{ab}} \pm 1.05$ & $0.55^{\mathrm{bc}} \pm 0.010$ \\
\hline Vit. $\mathrm{E}+\mathrm{Cr}$ & $11.10^{\mathrm{b}} \pm 0.26$ & $31.50^{\mathrm{ab}} \pm 0.10$ & $3.51^{b c} \pm 0.032$ & $31.59 \pm 0.52$ & $35.24 \pm 1.01$ & $89.66^{\mathrm{ab}} \pm 1.18$ & $0.54^{\mathrm{c}} \pm 0.064$ \\
\hline Vit. E+ Se & $11.80^{\mathrm{a}} \pm 0.30$ & $32.13^{\mathrm{a}} \pm 0.57$ & $3.86^{\mathrm{a}} \pm 1.0$ & $30.57 \pm 1.93$ & $36.72 \pm 1.63$ & $83.25^{b} \pm 1.53$ & $0.53^{c} \pm 0.015$ \\
\hline Vit. $\mathrm{E}+\mathrm{Cr}+\mathrm{Se}$ & $11.93^{\mathrm{a}} \pm 0.31$ & $32.16^{\mathrm{a}} \pm 1.0$ & $3.70^{\mathrm{ab}} \pm 0.051$ & $32.65 \pm 0.60$ & $37.14 \pm 0.29$ & $87.66^{\mathrm{ab}} \pm 1.85$ & $0.52^{c} \pm 0.015$ \\
\hline Significance & $*$ & $*$ & $*$ & NS & NS & $*$ & $*$ \\
\hline
\end{tabular}

$a, b, c$ Means $\pm S D$ within a column with different superscripts are significantly different $(P \leq 0.05)$.

$N S=$ non-significant,$*=P \leq 0.05$. 
Egyptian J. Nutrition and Feeds (2017), 20 (2) Special Issue

Table (8) . Effect of some dietary supplements and early age heat conditioning on Carcass characteristics of broiler chicks at 42 day of age.

\begin{tabular}{|c|c|c|c|c|c|}
\hline Treatment & Caracas $(\%)$ & Breast (\%) & Thigh (\%) & Liver $(\%)$ & Gizzard (\%) \\
\hline \multicolumn{6}{|l|}{ Heat conditioning $(\mathrm{HC})$ : } \\
\hline Non heat conditioning (NHC) & $69.15^{\mathrm{b}} \pm 2.21$ & $16.91^{\mathrm{b}} \pm 0.57$ & $12.51^{\mathrm{b}} \pm 0.44$ & $2.15^{\mathrm{a}} \pm 0.19$ & $1.16^{\mathrm{b}} \pm 0.06$ \\
\hline Heat conditioning $(\mathrm{HC})$ & $73.16^{\mathrm{a}} \pm 1.15$ & $17.67^{\mathrm{a}} \pm 0.19$ & $13.20^{\mathrm{a}} \pm 0.39$ & $2.10^{\mathrm{b}} \pm 0.05$ & $1.25^{\mathrm{a}} \pm 0.07$ \\
\hline Significance & $*$ & $*$ & $*$ & $*$ & $*$ \\
\hline \multicolumn{6}{|l|}{ Dietary supplements $(\mathrm{T})$} \\
\hline Control & $69.16^{\mathrm{b}} \pm 3.47$ & $16.76^{\mathrm{b}} \pm 0.75$ & $12.36^{\mathrm{b}} \pm 0.53$ & $2.31^{\mathrm{a}} \pm 0.168$ & $1.12^{\mathrm{b}} \pm 0.044$ \\
\hline Vit. E+ Cr & $71.38^{\mathrm{a}} \pm 1.89$ & $17.44^{\mathrm{a}} \pm 0.48$ & $12.84^{\mathrm{a}} \pm 0.51$ & $2.09^{\mathrm{b}} \pm 0.030$ & $1.22^{\mathrm{a}} \pm 0.076$ \\
\hline Vit. E+ Se & $72.50^{\mathrm{a}} \pm 2.45$ & $17.53^{\mathrm{a}} \pm 0.42$ & $13.14^{\mathrm{a}} \pm 0.49$ & $2.03^{\mathrm{c}} \pm 0.028$ & $1.25^{\mathrm{a}} \pm 0.055$ \\
\hline Vit. $\mathrm{E}+\mathrm{Cr}+\mathrm{Se}$ & $71.58^{\mathrm{a}} \pm 2.01$ & $17.44^{\mathrm{a}} \pm 0.21$ & $13.08^{\mathrm{a}} \pm 0.26$ & $2.07^{\mathrm{bc}} \pm 0.034$ & $1.24^{\mathrm{a}} \pm 0.077$ \\
\hline $\begin{array}{l}\text { Significance } \\
\text { interaction }\end{array}$ & \multicolumn{4}{|c|}{ interaction } & $*$ \\
\hline \multicolumn{6}{|l|}{ A-Non heat conditioning $(\mathrm{NHC}) \times$} \\
\hline Control & $66.23^{\mathrm{d}} \pm 1.72$ & $16.08^{\mathrm{d}} \pm 0.080$ & $11.89^{\mathrm{d}} \pm 0.136$ & $2.46^{\mathrm{a}} \pm 0.050$ & $1.09^{\mathrm{d}} \pm 0.010$ \\
\hline Vit. $\mathrm{E}+\mathrm{Cr}$ & $69.73^{c} \pm 0.55$ & $17.09^{c} \pm 0.453$ & $12.38^{c} \pm 0.064$ & $2.09^{c} \pm 0.043$ & $1.16^{\mathrm{cd}} \pm 0.061$ \\
\hline Vit. E+ Sel & $70.73^{b c} \pm 2.23$ & $17.23^{\mathrm{bc}} \pm 0.362$ & $12.93^{\mathrm{ab}} \pm 0.060$ & $2.01^{\mathrm{d}} \pm 0.005$ & $1.21^{\mathrm{abc}} \pm 0.015$ \\
\hline Vit. $\mathrm{E}+\mathrm{Cr}+\mathrm{Sel}$ & $69.73^{c} \pm 0.79$ & $17.26^{\mathrm{bc}} \pm 0.052$ & $12.85^{\mathrm{abc}} \pm 0.051$ & $2.06^{\mathrm{cd}} \pm 0.043$ & $1.18^{\mathrm{bc}} \pm 0.070$ \\
\hline \multicolumn{6}{|l|}{ B- heat conditioning $(\mathrm{HC}) \times$} \\
\hline Control & $72.10^{\mathrm{ab}} \pm 1.17$ & $17.45^{\mathrm{abc}} \pm 0.132$ & $12.83^{\mathrm{bc}} \pm 0.230$ & $2.16^{\mathrm{b}} \pm 0.023$ & $1.15^{\mathrm{cd}} \pm 0.045$ \\
\hline Vit. $\mathrm{E}+\mathrm{Cr}$ & $73.03^{a} \pm 0.72$ & $17.79^{\mathrm{a}} \pm 0.058$ & $13.30^{\mathrm{ab}} \pm 0.105$ & $2.10^{\mathrm{c}} \pm 0.015$ & $1.27^{\mathrm{ab}} \pm 0.050$ \\
\hline Vit. E+ Sel & $74.26^{\mathrm{a}} \pm 0.86$ & $17.83^{\mathrm{a}} \pm 0.198$ & $13.35^{\mathrm{a}} \pm 0.689$ & $2.06^{\mathrm{cd}} \pm 0.020$ & $1.28^{\mathrm{a}} \pm 0.065$ \\
\hline Vit. $\mathrm{E}+\mathrm{Cr}+\mathrm{Sel}$ & $73.26^{\mathrm{a}} \pm 1.01$ & $17.62^{\mathrm{ab}} \pm 0.101$ & $13.31^{\mathrm{ab}} \pm 0.095$ & $2.08^{\mathrm{c}} \pm 0.025$ & $1.30^{\mathrm{a}} \pm 0.020$ \\
\hline Significance & $*$ & $*$ & $*$ & $*$ & $*$ \\
\hline
\end{tabular}

${ }_{a, b, c}$ Means $\pm S D$ within a column with different superscripts are significantly different $(P \leq 0.05)$

$N S=$ non-significant, $*=P \leq 0.05$.

Table (9). Effect of some dietary supplements and early age heat conditioning on weights of some organs of broiler chicks at 42 day of age. 
Gouda et al.

\begin{tabular}{|c|c|c|c|c|c|}
\hline Treatment & Heart $(\%)$ & A.F $(\%)$ & Thymus (\%) & Bersa $(\%)$ & Spleen $(\%)$ \\
\hline \multicolumn{6}{|l|}{ Heat conditioning $(\mathrm{HC})$ : } \\
\hline Non heat conditioning (NHC) & $0.32^{\mathrm{b}} \pm 0.04$ & $1.12^{\mathrm{b}} \pm 0.02$ & $0.21^{\mathrm{b}} \pm 0.02$ & $0.12 \pm 0.008$ & $0.22 \pm 0.007$ \\
\hline Heat conditioning $(\mathrm{HC})$ & $0.35^{\mathrm{a}} \pm 0.03$ & $1.17^{\mathrm{a}} \pm 0.03$ & $0.23^{\mathrm{a}} \pm 0.01$ & $0.11 \pm 0.007$ & $0.22 \pm 0.005$ \\
\hline Significance & $*$ & $*$ & $*$ & NS & NS \\
\hline \multicolumn{6}{|l|}{ Dietary supplements $(\mathrm{T})$} \\
\hline Control & $0.30^{c} \pm 0.033$ & $1.12 \pm 0.039$ & $0.22 \pm 0.014$ & $0.12 \pm 0.008$ & $0.22 \pm 0.004$ \\
\hline Vit. $\mathrm{E}+\mathrm{Cr}$ & $0.34^{\mathrm{b}} \pm 0.032$ & $1.14 \pm 0.022$ & $0.22 \pm 0.017$ & $0.12 \pm 0.009$ & $0.21 \pm 0.005$ \\
\hline Vit. $\mathrm{E}+\mathrm{Se}$ & $0.37^{\mathrm{a}} \pm 0.012$ & $1.15 \pm 0.039$ & $0.23 \pm 0.014$ & $0.11 \pm 0.005$ & $0.21 \pm 0.007$ \\
\hline Vit. $\mathrm{E}+\mathrm{Cr}+\mathrm{Se}$ & $0.36^{\mathrm{ab}} \pm 0.017$ & $1.15 \pm 0.030$ & $0.23 \pm 0.014$ & $0.11 \pm 0.005$ & $0.21 \pm 0.005$ \\
\hline Significance & $*$ & NS & NS & NS & NS \\
\hline \multicolumn{6}{|l|}{ interaction } \\
\hline \multicolumn{6}{|l|}{ A-Non heat conditioning $(\mathrm{NHC}) \times$} \\
\hline Control & $0.28^{\mathrm{c}} \pm 0.032$ & $1.11^{\mathrm{d}} \pm 0.026$ & $0.21 \pm 0.010$ & $0.12 \pm 0.005$ & $0.22 \pm 0.005$ \\
\hline Vit. E+ Cr & $0.31^{\mathrm{bc}} \pm 0.015$ & $1.13^{\mathrm{cd}} \pm 0.020$ & $0.21 \pm 0.010$ & $0.12 \pm 0.011$ & $0.22 \pm 0.005$ \\
\hline Vit. E+ Sel & $0.36^{\mathrm{a}} \pm 0.011$ & $1.12^{\mathrm{cd}} \pm 0.010$ & $0.22 \pm 0.010$ & $0.11 \pm 0.005$ & $0.21 \pm 0.010$ \\
\hline Vit. $\mathrm{E}+\mathrm{Cr}+\mathrm{Sel}$ & $0.34^{\mathrm{ab}} \pm 0.011$ & $1.13^{\mathrm{cd}} \pm 0.010$ & $0.23 \pm 0.026$ & $0.12 \pm 0.005$ & $0.22 \pm 0.005$ \\
\hline \multicolumn{6}{|l|}{ B- heat conditioning $(\mathrm{HC}) \times$} \\
\hline Control & $0.31^{b c} \pm 0.035$ & $1.14^{\mathrm{bcd}} \pm 0.047$ & $0.23 \pm 0.010$ & $0.11 \pm 0.011$ & $0.22 \pm 0.010$ \\
\hline Vit. E+ Cr & $0.36^{\mathrm{a}} \pm 0.023$ & $1.16^{\mathrm{abc}} \pm 0.020$ & $0.23 \pm 0.015$ & $0.11 \pm 0.005$ & $0.22 \pm 0.005$ \\
\hline Vit. E+ Sel & $0.38^{\mathrm{a}} \pm 0.005$ & $1.19^{\mathrm{a}} \pm 0.010$ & $0.24 \pm 0.015$ & $0.11 \pm 0.005$ & $0.21 \pm 0.005$ \\
\hline Vit. $\mathrm{E}+\mathrm{Cr}+\mathrm{Sel}$ & $0.37^{\mathrm{a}} \pm 0.011$ & $1.18^{\mathrm{ab}} \pm 0.005$ & $0.23 \pm 0.010$ & $0.11 \pm 0.005$ & $0.22 \pm 0.005$ \\
\hline Significance & $*$ & $*$ & NS & NS & NS \\
\hline
\end{tabular}

$a, b, c$ Means $\pm S D$ within a column with different superscripts are significantly different $(P<0.05)$.

$N S=$ non-significant, $*=P \leq 0.05$. 


\section{REFERENCES}

Abdukalykova, S., and C. A. Ruiz-Feria (2006). Arginine and vitamin E improve the cellular and humoral immune response of broiler chickens. Int. J. Poult. Sci., 5: 121-127.

Ahmed M. H. and P. G. Reddy (2012). Early Age Thermal Conditioning Improves Broiler Chick's Response to Acute Heat Stress at Marketing Age. American J. of Anim. and Vet. Sci. 7 (1): 1-6.

Ali, M.S. and M.M. Hossain, (2010). Factors influencing the performance of farmers in broiler production of Faridpur District in Bangladesh. World's Poult. J. 66: 123-131.

Amiri A. M.; M. Shivazad; S. A. Pourbakhsh; M. Afshar; H. Rokni; N. E. Shiri; A. Mohammadi, and Z. Salahi (2006). Effects of vitamin E in broiler breeder diet on hatchability, egg quality and breeder and day old chick immunity. Pakistan J. Biol. Sci., 9:789-794.

Aslam, F.; Khan, M. Z.; Khan, S.; Sharaf, S. T.; Gulang, M. K. and Saleemi M. K. (2010): toxicopathological changes induced by cypermethrin in broiler chicks: their attenuation with Vitamin $\mathrm{E}$ and selenium. Experimental and Toxicologic, 62: 441-450.

Biswas, A.; J. Mohan; K. V .H. Sastry, and J .S. Tyagi (2007). Effect of dietary Vitamin E on the cloacal gland, foam and semen characteristics of male Japanese quail. Theriogenol., 67: 259-263.

Boa-Amponsem, K.; M. Picard; M. E. Blair; B. Meldrum, and P. B. Siegel (2006). Memory antibody responses of broiler and Leghorn chickens as influenced by dietary vitamin $\mathrm{E}$ and route of sheep red blood cell administration. Poult. Sci., 85:173-177.

Burton, G. M. and M. G. Traber (1990). Vitamin E: Antioxidant activity, biokinetics, and bioavailability. Annu. Rev. Nutr. 10:357-382.

Elaroussi, M. A.; M. A. Fattah; N. H. Meky ; I. E. Ezzat , and M. M. Wakwak (2007). Effects of vitamin $\mathrm{E}$, age and sex on performance of Japanese quail. 1. Haematological indices and liver function. Br. Poult. Sci., 48:669-77.

El-Moniary, M. M. A; A. A. Hemid; I. El-Wardany; A.E. Gehad and A. Gouda.(2010). The effect of early age heat conditioning and some feeding programs for heat-stressed broiler chicks on: 1 Productive Performance. World J. of Agri. Sci. 6 (6): 689-695.

El-Sheikh, A.M.H.; E.A. Abdella and M.M. Hanafy (2010). The effect of organic selenium supplementation on productive and physiological performance in a local strain of chicken.2- immune system and some physiological aspects in bandarah chicks affected by organic selenium. Egypt. Poult. Sci. Vol (30) (II): (517-533).

El-Wardany I.; M.M.A. El-Moniary; A.A. Hemid; A.E. Gehad and A. Gouda (2012). The effect of early age heat conditioning and some feeding programs for heat-stressed broiler chicks on: 2. physiological responses immunological response. Egyptian J. Nut. and Feeds (2012), 15 (1) Special Issue:

Ghazi, Sh.; M. Habibian; M. M. Moeini and A. R. Abdolmohammadi (2012). Effects of Different Levels of Organic and Inorganic Chromium on Growth Performance and Immunocompetence of Broilers under Heat Stress. Biol Trace Elem Res 146:309-317

Hanafy M.M.; A.M.H. El-Sheikh, and E.A. Abdella (2009).The effect of organic selenium supplementation on productive and physiological performance in a local strain of chicken. 1- The effect of organic selenium (sel-plex) on productive and physiological traits of Bandarah strain. Egypt.Poult. Sci., 29: 10611084.

Helmersson, J.; J. Arnlov; B. Vessby; A. Larsson; G. Alfthan and S. Basu (2005). Serum selenium predicts levels of F2-isoprostanes and prostaglandin F2alpha in a 27 year follow-up study of Swedish men. Free Radic. Res.39, 763-770.

Hemid A. A., I. El-Wardany, M. M. A. El-Moniary, A. E. Gehad and A. Gouda (2013). The effect of early age heat conditioning and some feeding programs for heat-stressed broiler chicks on: (3). immunological Response. Egyptian J. Nut. and Feeds, 16 (2) Special Issue: 297-308.

Hossain, S. M.; S. L. Barreto; A. G. Bertechini; A. M. Rios, and C. G. Silva (1998). Influence of dietary vitamin E level on egg production of broiler breeders, and on the growth and immune response of progeny in comparison with the progeny from eggs injected with vitamin E. Anim. Feed Sci. Techol., 78:307-317.

Jiakui, L. and W. Xiaolong (2004). Effect of dietary organic versus inorganic selenium in laying hens on the productivity, selenium distribution in egg and selenium content in blood, liver and kidney. J. Trace Elem Med Biol 18:65-68

Jiang, Z.; Y. Lin; G. Zhou; L. Luo; S. Jiang and F. Chen (2009). Effects of Dietary Selenomethionine Supplementation on Growth Performance, Meat Quality and Antioxidant Property in Yellow Broilers. J. Agric. Food Chem. 57, 9769-9772

Kubena, L.F., J.D. May, F.N. Reece and J.W. Deaton, (1972). Hematocrit and hemoglobin levels of broilers as influenced by environmental temperature and dietary iron level. Poult. Sci., 51: 759-763. 


\section{Gouda et al.}

Leshchinsky T. V. and K. C. Klasing, (2001). Relationship between the Level of dietary vitamin E and the immune response of broiler chickens. Poult. Sci. 80:1590-1599.

Lien, T. F.; Y. M. Horng, and K. H. Yang (1999). Selenium on erythrocyte and liver glutathione peroxidase in the rat, Performance, serum characteristics, carcass traits and lipid metabolism of broilers as affected by supplement of chromium picolinate, Br. Poult. Sci. 40(3), 357-361.

Lin, H.; R. Du and Z.Y. Zhang (2000). The peroxidation in tissues of heat-stressbroilers. AsianAustralas. J. Anim. Sci. 13, 1373-1376.

Moreno-Reyes, R.; D. Egrise; J. Nève; J.L. Pasteels and A. Schoutens (2001). Selenium deficiencyinduced growth retardation is associated with an impaired bone metabolism and osteopenia. J. Bone Miner Res16 (8):1556 - 63.

Mujahid, A.; K. Sato; Y. Akiba and M. Toyomizu, (2006). Acute heat stress stimu- lates mitochondrial superoxide production in broiler skeletal muscle, possibly via downregulation of uncoupling protein content. Poult. Sci. 85, 1259-1265.

Mujahid, A.; N.R. Pumford; W. Bottje; K. Nakagawa; T. Miyazawa; Y. Akiba and M. Toyomizu (2007). Mitochondrial oxidative damage in chicken skeletal muscle induced by acute heat stress. J. Poult. Sci. 44, 439-445.

Mujahid, A.; Pumford, N. R.; Bottje, W.; Nakagawa, K.; Miyazawa, T.; Akiba, Y. and Toyomizu, M. (2008). Mitochondrial oxidative damage in chicken skeletal muscle induced by acute heat stress. J. Poult. Sci. 44, 439-445.

Muller DP (2010). Vitamin E and neurological function. Review. Mol. Nutr. Food Res 54 (5): 710-718.

Natt, M. P; Herrick C. A. 1952 A new diluents for counting the Erythrocytes and leukocytes for chickens. Poult. Sic., 31:735-8.

Niu, Z.Y.; F.Z. Liu; Q. L. Yan and W.C. Li (2009). Effects of different levels of vitamin E on growth performance and immune responses of broilers under heat stress. Poult. Sci., 88, 2101-2107.

Patton, N. D.; A.H. Cantor; A.J. Pescatore; M.J. Ford and C.A. Smith (2002). The effect of diet ary selenium source and level on the uptake of selenium by developing chick embryos. Poult. Sci. 81, $1548-1554$.

Sahin K.; O. Kucuk; N. Sahin and O. Ozbey (2001). Effects of dietary chromium picolinate supplementation on egg production, egg quality, and serum concentrations of insulin, corticostrerone and some metabolites of Japanese Quails. Nut. Res. 21(9):1315-1321.

Sahin, K.; N. Sahin and O. Kucuka (2003). Effects of chromium, and ascorbic acid supplementation on growth, carcass traits, serum metabolites, and antioxidant status of broiler chickens reared at a high ambient temperature. Nutr. Res., 23: 225-238.

Sahin, K.; N. Sahin; M. Onderci; F. Gursu and G. Cikim, (2002). Optimal dietary concentration of chromium for alleviating the effect of heat stress on growth, carcass qualities and some serum metabolites of broiler chickens. Biol. Trace Elet. Res., 89: 53-64.

Sahin, N.; M. Onderci; K. Sahin and O. Kucuk (2008). Supplementation with organic or inorganic selenium in heat-distressed quail. Biological Trace Element Res. 122:229-237.

Sands, J. S. and M. O. Smith (2002). Broilers in heat stress conditions: Effects of dietary Manganese proteinate or Chromium picolinate supplementation. J. Appl. Poultry. Res. 8: 280 -287.

SAS Institute. (1999). SAS User's Guide. Version 8.02 ed. SAS Institute Inc., Cary, NC.

Ševčíková, S.; M. Skrivan; G. Dlouha and M. Koucky (2006). The effect of selenium source on the performance and meat quality of broiler chickens. Czech J. Anim. Sci. 51: 449-457.

Siegel, P. B.; S. E. Price; B. Meldrum; M. Picard, and P. A. Geraert (2001). Performance of pureline broiler breeders fed two levels of vitamin E. Poult. Sci., 80:1258-1262.

Skřivan, M.; M. Marounek; G. Dlouhá; and S. Ševčíková. (2008). Dietary selenium increases vitamin E contents of egg yolk and chicken meat. Br. Poult. Sci. 49:482- 486.

Smith, J.; J. Harner; D. Durham; J. Stevenson; J. Shirley; G. Stokka and M. Meyer (1998). Coping with summer weather; Dairy management strategies to control heat stress. Kansas State University. USA.

Spears, J. W.; J. Grimes; K. Lloyd, and T. L. Ward (2003). Efficacy of a novel organic selenium compound (zinc-L-selenomethionine, availaSe) in broiler chicks. 1st Latin American Congress of Animal Nut., Cancun: 197-198.

Surai, P. F. (2006). Selenium in nutrition and health. Nottingham University Press, Nottingham, United Kingdom.

Surai, P.F., (2002). Selenium in poultry nutrition 1. Antioxidant properties, deficiency and toxicity. World's Poult. Sci. J. 58:333- 346.

Tietz, N. W. (1990). Clinical guide to laboratory tests. $2^{\text {th }}$ Ed. Philadelphila: WB, Saunders; 566.

Toghyani, M.; M. Shivazad; A.A. Gheisari and S.H. Zarkesh, (2006). Performance, Carcass Traits and Hematological Parameters of Heat-Stressed Broiler Chicks in Response to Dietary Levels of Chromium Picolinate. Int. J. of Poult. Sci. 5 (1): 65-69. 
Utterback, P. L.; C. M. Parsons; I. Yoon and J. Butler (2005). Effect of supplementing selenium yeast in diets of laying hens on egg selenium content, Poult. Sci., 84: 1900-1901.

Ward, T. L., L. L. Southern, and S. L. Boleman. (1993). Effect of dietary chromium picolinate on growth, nitrogen balance and body composition of growing broiler chicks. J. Anim. Sci. 73 (Suppl.1):37. (Abstr.)

Wilson, W.O., (1971). Evaluation of stressor agents in domestic animals. J. Anim. Sci., 32: 578-583.

Wolf, G. 2005. The discovery of the antioxidant functions of vitamin E: the contribution of Henry A. Mattill. J. Nutr. 135:363-366.

World Meteorological Organization (W.M.O). (1996). Guide to meteorological instruments and methods of observation. Sixth edition. Geneva, Switzerland.

Yahav S. (1998). The effect of acute and chronic heat stress on performance and physiological responses of domestic fowl. Trends Biochem Physiol. 5: 187-194.

Yahav S. (2000). Domestic fowl strategies to confront environmental conditions. Poult. Avian Bio. Rev 11: 81-95,

Yahav S. and S. Hurwitz (1996). Induction of thermotolerance in male broiler chickens by temperature conditioning at an early age. Poult Sci 75: 402-406.

Yahav S.; A. Straschnow; I. Plavnik and S. Hurwitz (1997): Blood system response of chickens to changes in environmental temperature. Poult. Sci., 76, 627-633.

Yahav, S. and I. Plavink, (1999). Effect of early age thermal condition and food restriction on performance and thermotolerance of male broiler chickens. Br. Poult. Sci., 40: 120-126.

Yahav, S.; D. Shinder; S. Cohen; J. Tanny; and S. Cohen (2005). Sensible heat loss: the broiler's paradox. World's Poult. Sci. J. 61: 410-435.

Yahav, S.; R. Sasson Rath; and D. Shinder (2004). The effect of thermal manipulations during embryogenesis of broiler chicks (Gallus domesticus) on hatchability, body weight and thermoregulation after hatch. J. of Thermal Biology 29: 245-250.

Yang, Y. R.; F. C. Meng; P. Wang; Y. B. Jiang; Q. Q. Yin; J. Chang; R. Y. Zuo1; Q. H. Zheng and J. X. Liu (2012) Effect of organic and inorganic selenium supplementation on growth performance, meat quality and antioxidant property of broilers. African J. of Biotechnology Vol. 11(12), pp. 3031-3036.

Zhou, X. and Y. Wang (2011). Influence of dietary nano elemental selenium on growth performance, tissue selenium distribution, meat quality, and glutathione peroxidase activity in Guangxi Yellow chicken. Poult. Sci. 90:680-686.

Zulkifli, I; M. T. Che-Norma; D. A. Israf and A. R. Omar (2002). The effect of early-age food restriction on heat shock protein70 response in heat-stressed female broiler chickens. Br. Poult. Sci. 43: 141-145. 
الاستجابات الفسيولوجيه لاجاج التسمين المتاثره بالتهيئة الحراريه في عمر مبكر واضافة بعض مضادات الاكسده الى العلائق العيول

أحمد جوده عبدالله'، مسعد محمد علي المنيري'، إيمان فرج الدالي' ، ابراهيم الورداني السيد` وعلاءالدين عبدالسلام حميد 'قسم الاتتاج الحيواني - شعبة البحوث الزراعية والبيولوجية ـ المركز القومي للبحوثـ الدقي - الجبزه- مصر. "قسم انتاج الدواجن ـ كلية الزراعه ـ جامعة عين شمس- شبرا الخيمه ــ القاهرهـ مصر.

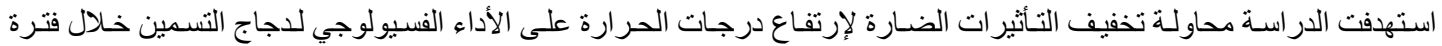

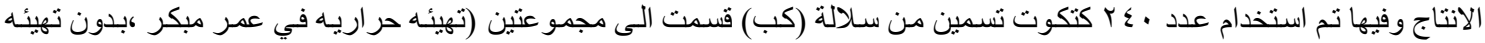

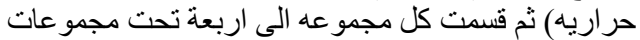

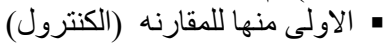

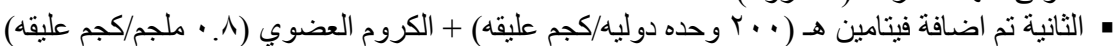

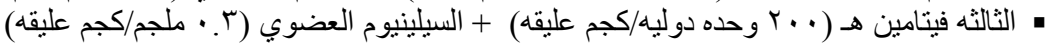

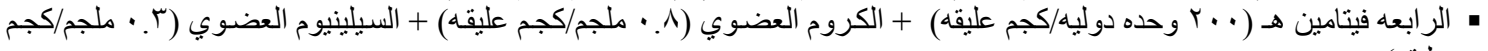
عليقه).

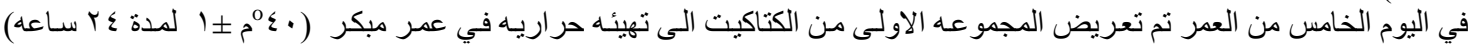

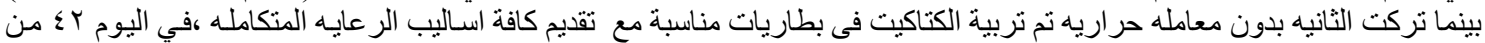

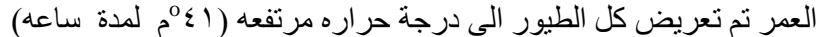

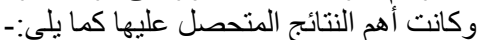

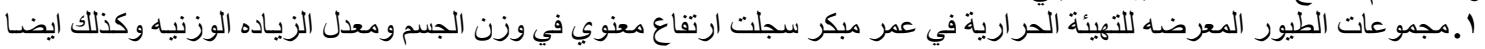

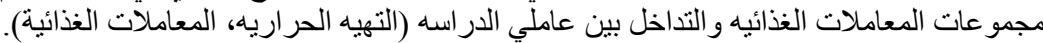

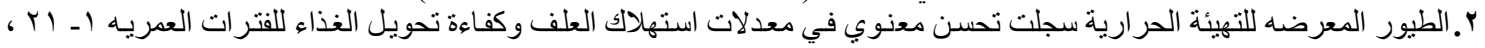

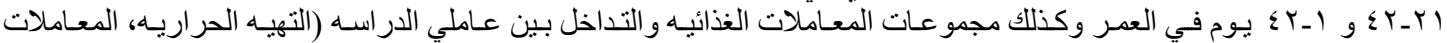

الغذائية).

"ا.وجد تحسن معنوي في بعض قياسات الدم المدروسه وكذلك نسبة كرات الدم البيضاء الليمفاوية إلى المتعادلة لصالح مجمو عات الطيور

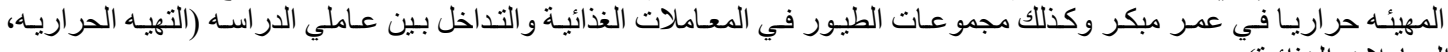

